\title{
SÉHUL A JEJ PODOBY V HMOTNEJ KULTÚRE DOBY BRONZOVEJ
}

\author{
D UŠA N VALENT - PAVOL J E L ÍN E K
}

\begin{abstract}
Séhul and Her Representations in the Material Culture of the Bronze Age. The Bronze Age solar cult of the Carpathian Basin represents autochtonous central-European development with Indo-European roots. It was centered on a deity perceived in anthropomorphic, probably feminine form. We stress the complementarity of archeology and Indo-European comparative mythology in the pursuit to better understand its cult. We also argue that its potential approximation - the Proto-Indo-Europan solar deity, in contrast to its Middle-Eastern counterparts, did not enter a subterranean underworld and was not associated with rebirth, but most likely with the desired destination in the afterlife, which may lead to different interpretations of some cult-related archeological finds.
\end{abstract}

Keywords: Carpathian Basin, Bronze Age, solar deity, anthropomorphic pendants, Indo-European mythology.

\section{ÚVOD}

Pre dobu bronzovú, najmä jej mladšiu čast', je charakteristická solárna symbolika, obzvlášt solárna výzdoba prestížnych predmetov, ktorú bádatelia oprávnene dávajú do súvisu s uctievaním Slnka (Green 1991, 33-60). Dominancia slnečných motívov v podobe rozetiek, svastík, koncentrických krúžkov a najvýraznejšie $\mathrm{v}$ zobrazeniach tzv. slnečných vozíkov a bárok viedla, a tu vidíme dôvod na opatrnost', niektorých našich predchodcov (napr. Bouzek 1977; Paulík 1999; 2000; Podborský 2006; Švecová 2004 a i.) k záveru, že slnečné božstvo bolo najvyšším božstvom panteónu (napr. J. Paulík viackrát píše o slnečnom henoteizme) vo vtedajších náboženských systémoch.

V pilotnom texte (Jelínek/Valent 2019) sme sa priklonili k záveru, že niektoré antropomorfné, ale aj iné ikonografie indikujú ženské atmosférické, v niektorých prípadoch slnečné božstvo, vzhladom na postavenie $\mathrm{v}$ čase a priestore pravdepodobne blízke praindoeurópskemu (PIE) prototypu neskorších indoeurópskych božstiev slnka. V tomto texte sa sústredíme na identifikáciu potenciálnych antropomorfných zobrazení tohto božstva a na načrtnutie niektorých jeho dôležitých charakteristík.

\section{SLNKO AKO ANTROPOMORFNÉ BOŽSTVO}

Z porovnávacej mytológie vyplýva, že indoeurópske božstvá sa vnímali (aj) v ludskej podobe už od najskorších čias (West 2007, 138). Vzácnost’ či údajná absencia stredoeurópskych antropomorfných zobrazení božstiev v dobe bronzovej evokuje ich absenciu v ranom hinduizme (Kaliff 2007, 49) napriek skutočnosti, že v rigvédskej tradícii vy- stupujú božstvá aj v jednoznačne antropomorfnej podobe (Keith 1925, 58). Existujú početné príklady neantropomorfných symbolov reprezentujúcich antropomorfné božstvo. Antropomorfne vnímaná baltská slnečná bohyňa Saule sa napríklad zobrazuje ako prstenec, kruh, koleso, rozeta a sedmokráska (Gimbutas 1963, 201) a chetitské rituálne formuly explicitne uvádzajú, že slnečné disky reprezentujú slnečnú bohyňu z Arinny (Haas 1994, 424). Obdobnú interpretáciu symbolov slnka podporujú aj detailné paralely medzi symbolickými vyobrazeniami slnka $\mathrm{v}$ dobe bronzovej a indoeurópskymi tradíciami asociovanými s antropomorfnými božstvami (pozri nižšie). Uvedené skutočnosti oprávňujú interpretovat' antropomorfné zobrazenia doby bronzovej ako zobrazenia božstiev a falzifikujú hypotézu, že absencia antropomorfných vyobrazení implikuje kult neantropomorfnej prírodnej sily. Božstvá doby bronzovej boli každopádne najčastejšie zobrazované tak, ako ich ludia videli, teda v podobe symbolov prírodných a astronomických javov (obr. 1).

\section{ANTROPOMORFNÉ SOLÁRNE ZOBRAZENIA}

V staršej dobe bronzovej v Karpatskej kotline a v širšej stredodunajskej oblasti evidujeme antropomorfné zobrazenia. Ide o plastiky alebo abstrahované postavy vyryté na keramike, vytepané do plechových ozdôb hlavy alebo odliate do podoby záveskov (podrobne Jelínek/Valent 2019). Niektoré z nich majú rovnaké stvárnenie $\mathrm{v}$ kovovom prevedení alebo v keramike a objavujú sa vo viacerých súčasných či následných kultúrach. Považujeme ich za božstvá. Hovoríme preto o náboženských ikonografiách.

K najstarším zobrazeniam spojeným so solárnou symbolikou patrí mušlovinový terčík z Podlešian, 


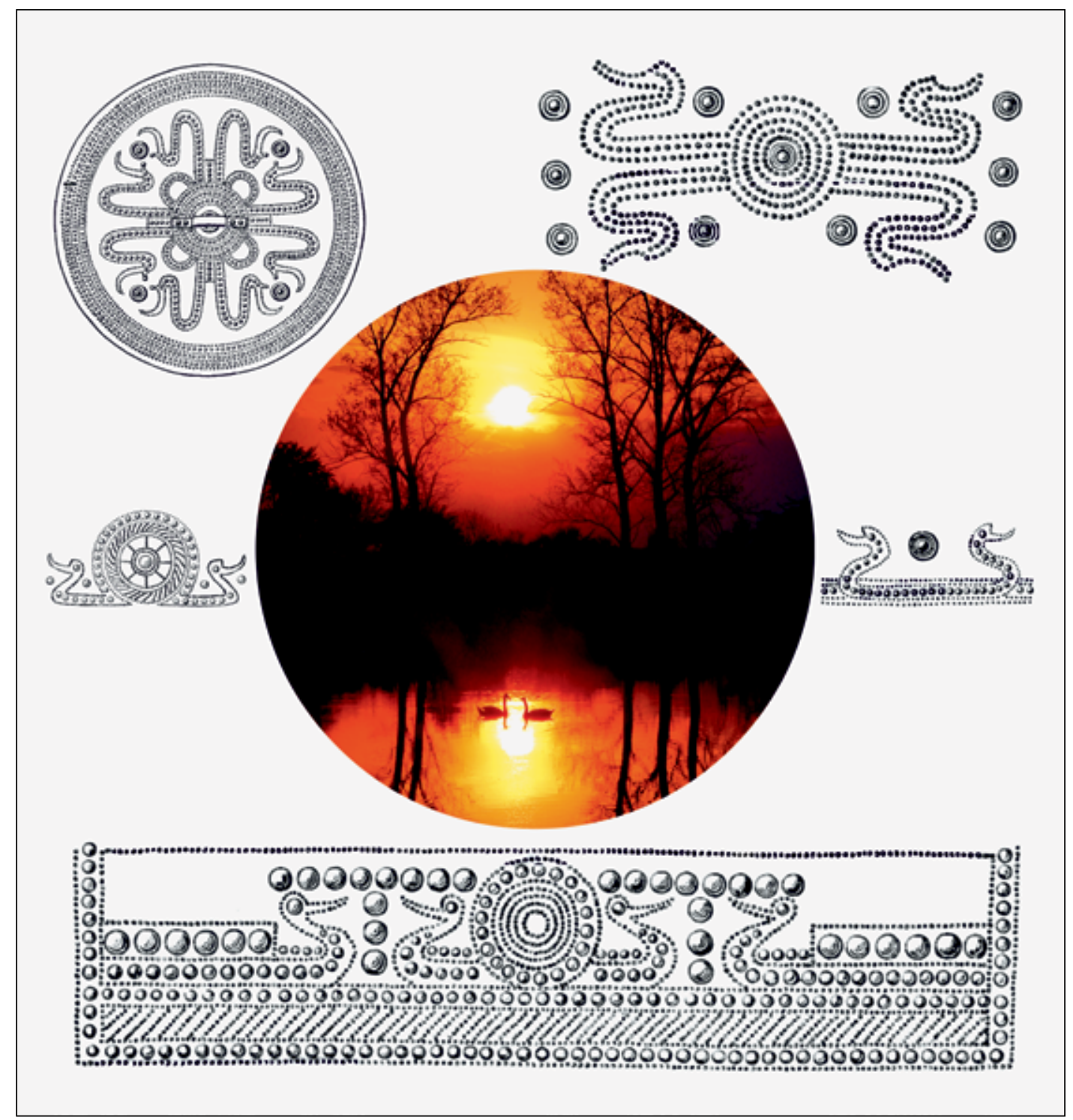

Obr. 1. Slnečné symboly doby bronzovej (podla Kossack 1954, tab. 8: 15-17; 9: 4, 5) a ich prírodný vzor (foto F. Tóth).

ktorý bol súčastou náhrdelníka z korálikov a zvieracích zubov (Buchvaldek a i. 1997, 191, obr. 19). Žial' nie sú $\mathrm{k}$ nemu dostupné nálezové okolnosti, autori predpokladajú, že ide o hrobový nález. Prirad’ujú ho k neskoroeneolitickej kultúre so šnúrovou keramikou, kde sa podobné terčíky vyskytujú v ženských hroboch (Mandausová 2012). Bývajú však zdobené symbolom kruhu s krížom, resp. štvorspicového kolesa, ktoré sa interpretuje ako solárny symbol (Green 1991, 39-44). S najväčšou pravdepodobnostou tak môžeme uvažovat', že postavička na náleze je tiež asociovaná so slnečnou symbolikou.

Štvorspicové kolesá a ich zobrazenia sa v staršej dobe bronzovej objavujú na terčovitých ihliciach, bronzových záveskoch, samostatne vyrobené $\mathrm{z}$ hliny alebo $\mathrm{v}$ rytej výzdobe keramických nádob.
Ich spojitost' so slnkom je možné odvodit od optického javu, tzv. parhélia (Jelínek/Valent 2019, 60) a patria $\mathrm{k}$ najrozšírenejším solárnym symbolom $\mathrm{v}$ dobe bronzovej. $\mathrm{Z}$ chronologického hladiska tak o predstave slnečného kolesa alebo voza môžeme uvažovat' už v staršej dobe bronzovej.

Tzv. slnečná bárka sa ako solárny symbol objavuje od strednej doby bronzovej. Jozef Paulík sa viackrát (napr. Paulík 1999; 2000) snažil identifikovat' ju v starobronzovom materiáli, ale pri kritickom pohlade nie je tento názor udržatelný. Oba symboly od strednej doby bronzovej zachytávame nielen samostatne, ale vzácne aj v spojitosti s antropomorfnou postavou.

Medzi najstaršie patria starobronzové antropomorfné závesky (obr. 2). Poznáme ich z viacerých 


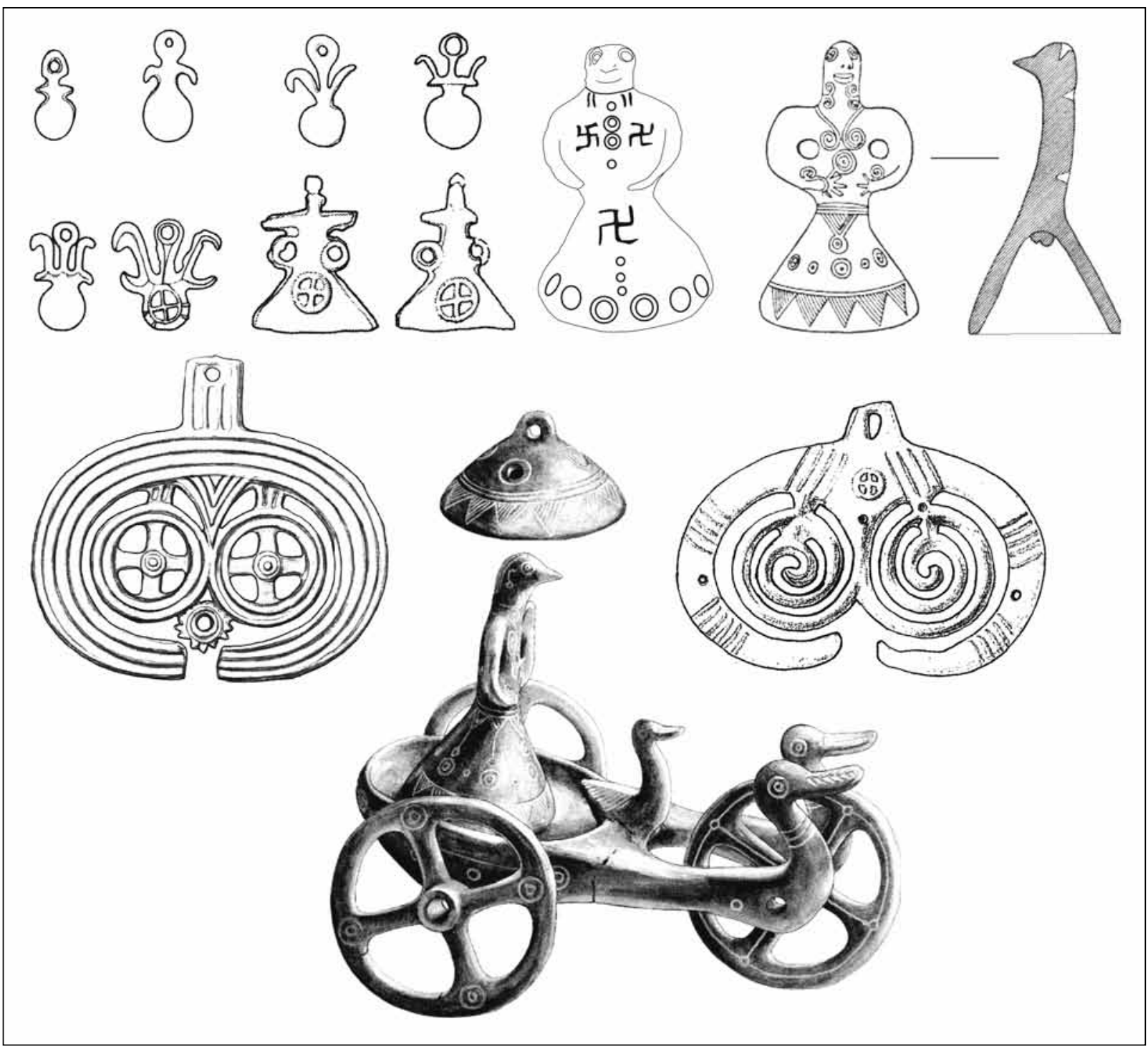

Obr. 2. Antropomorfné závesky so slnečnou symbolikou, plastiky a vozík z Dupljaje (podla Jankovits 2017, tab. 30: 988, 990, 991, 994-996, 1002, 1003; 43: 1290, 1294; Podborský 2006, tab. 56: 4).

lokalít v Mad’arsku. Zrejme k najstarším patrí exemplár z Ögerlaku a depotu B z Kölesd-Nagyhangos (Jankovits 2017, 366, tab. 30: 991-995). Vyskytujú sa aj zobrazené na keramike (Kiss 2012, 107, 104, obr. 33: 9). Na ne typologicky nadväzujú závesky typu Nagyhangos z depotu A (Jankovits 2017, 366, tab. 30: 988-990). Na exemplároch z Včeliniec, Oszláru a najnovšie z Neumarktu an der Ybbs (Reiter 2014) pribúda aj plastická výzdoba "brucha“ v podobe štvorspicového kolesa. Niektorí bádatelia (Hänsel 2012; Paulík 1999, 39) závesky typu Včelince a Nagyhangos interpretujú ako bárku s konskými, resp. vtáčími protómami nesúcu slnečný kotúč. Podla nášho názoru (Jelínek/Valent 2019, 60) staršie exempláre mali (ženský) antropomorfný tvar, ktorý sa však v čase kosziderského horizontu postupne zmenil. Prívesky pripomínajúce ludskú postavu s rukami v adoračnom geste boli dotvorené o solárny symbol kolesa a vystreté ruky sa zároveň premenili aj na konský a neskôr na vtáčí potah.

Typologický vývoj antropomorfných záveskov uzatvárajú nálezy z Kőszegu alebo Battiny (Jankovits 2017, 366, tab. 30: 1002, 1003), ktoré stvárňujú ženskú postavu s rukami vbok $\mathrm{s}$ vyobrazením štvorspicového kolesa $\mathrm{v}$ priestore brucha.

Podobnú symboliku majú aj lunicovité gynekomastonomorfné závesky z Nagyrozvágy a z Kisterénye (Jankovits 2017, 377-380, tab. 41: 162A, 162B; 42: 1278, 1288; 43; 44: 1295, 1296). Tieto plechové a liate závesky zobrazujú ženské torzo s naznačenými kruhovými šperkami, prsnými špirálami alebo prsníkmi v podobe slnečných kolies a so záveskom 
štvorspicového kolieska alebo vyrytými slniečkami, čo podla nášho názoru identifikuje slnečnú bohyňu.

Uvedené závesky majú svoj pendant $v$ keramike, v stvárnení vozíkov z Dupljaje (Podborský 2006, 232, tab. 56: 4, 5), na ktorých vidíme ženské postavy s vtáčími tvárami/maskami (?) idúce na vozíkoch, $\mathrm{v}$ jednom dochovanom prípade tahaných vodnými vtákmi. Na postavách aj vozíkoch sú znázornené solárne symboly v podobe kolies s vpísaným krížom na spodnej strane vozíka, ale najmä koncentrických kruhov a svastík umiestnených v oblasti brucha, za ktoré sa sošky držia, čím sa ikonograficky zhodujú so záveskami z Kőszegu alebo Battiny. Práve nálezy z Dupljaje vyššie citovaných bádatelov viedli k interpretácii slnečného božstva doby bronzovej ako „božstva apolónskeho typu“, pričom zjavný rozpor medzi typicky ženskou figúrkou a mužským antickým božstvom prekonávali pomocou rôznych transgenderových vysvetlení (viac v diskusii).

Ďalšie antropomorfné postavy spojitelné so slnečným božstvom sú postavy vezúce sa na bárkach (obr. 3). V karpatskom prostredí ich nenachádzame. Zdá sa, že sú spojené so severským okruhom, v stredoeurópskom priestore ich nachádzame v Pol'sku. Ide zväčša o plechové diadémy s tepanou výzdobou, kde sú zrkadlovo $\mathrm{k}$ sebe obrátené silne štylizované bárky nesúce trojicu postavičiek stvárnených zväzkom troch línií ukončených tromi väčšími hlavičkami. Podobné stvárnenie ludských postáv vidíme napríklad na rytine lode na meči z Rørby (Kristiansen 2013, 433, obr. 1). Takéto zobrazenia sú známe $\mathrm{z}$ diadémov v Marcinkowiciach, Łazarowiciach, Wojdale (Blajer 1990, 163, tab. XI: 4; Gedl 1975, tab. III: 5, 11; Machnik a i. 1978, 155, obr. 61). Podobné stvárnenie je aj na čelenke v Bonine (Kersten 1958, tab. 83: 758: c) a na opasku v Rościęcine (Blajer 1990, tab. LXXXVIII: 1; Kersten 1958, tab. 89: 801a, b). Tu už je zobrazenie štylizované na hranicu rozpoznania. Tento nález je dôležitý, pretože na opasku sú zobrazené aj solárne symboly v tvare štvorspicových kolies, čo by mohlo naznačovat funkciu postáv na lod'kách. Triadické kompozície na lod'kách pôsobia ako ikonografická skupina s vlastným zrozumitelným významom. Pripomínajú skalný obraz zo Sotetorpu v Bohusläne (Kaul 2008), kde je na lodi zobrazená ,,akrobatka“ sprevádzaná dvomi bojovníkmi. Odlišujú sa od iných, rôznorodejších, figurálnych scén známych zo severského skalného umenia alebo zobrazení na britvách (napr. Podborský 2006, 234, tab. 58). Zdá sa, že do karpatského prostredia v strednej dobe bronzovej prenikajú severské motívy zrkadlovo stvárnených lodí. Vidíme ich na diadémoch z Ócsi v Mad’arsku (Bóna 1992, 61, obr. 28) alebo rakúskeho Pittenu (Slaná 2019, 442, tab. II). Okrem spomínaného nálezu z Boninu je ale postavy na bárkach tažko asociovat’ so Slnkom.

\section{POVAHA A FUNKCIA SLNEČNÉHO BOŽSTVA}

Indoeuropeizácia strednej Európy prebehla zrejme počas 3. tisícročia pred n. 1. (Anthony 2017). Pre interpretáciu (nielen slnečného) kultu doby bronzovej v Karpatskej kotline preto môžeme zohladnit zistenia komparatívnej indoeurópskej mytológie a predpokladat vieru v božstvá blízke rekonštruovanému PIE panteónu.

Viaceré indície naznačujú existenciu PIE prototypu pre mnohé indoeurópske božstvá slnka:

Mená vychádzajúce z PIE výrazu pre slnko *Séh ul (resp. *Séh wl; Pinault 2017): grécky Hélios, rímsky Sol, germánska Sunna, nordická Sól, védsky Súrja, baltská Saule, chetitské božstvo ${ }^{\mathrm{d} U T U}$-li-i-aš ( ${ }^{*}$ Sahhulias), avestský Huuarə alebo Huuarə Xšaēta („,slnko“ resp. „Žiarivé slnko“), keltská Sulis (?), slovanský „Car Solnce“ (Dažbog; West 2007, 194, 195; Wodtko/Irslinger/Schneider 2008, 606-611).

Podobné základné črty (West 2007, 198-208, 227-233): o. i., indoeurópske božstvá slnka sa považovali za "vševidiace“, privolávali sa ako svedok prísah a križovali oblohu tahané koňmi, ktoré sú označované za neúnavné a rýchle a mali dcéru.

Komplexné spoločné mytologické pozadie: príbeh o diurnálnej púti božského slnka v sprievode rôznych pomocníkov a protivníkov, ktorý rekonštruoval F. Kaul $(1998 ; 2018,240)$ na základe vyobrazení na prestížnych nordických britvách doby bronzovej. Nachádza detailné paralely v gréckej, baltskej a védskej mytológii ${ }^{1}$ (Massetti 2019; Massetti, v príprave). Vyobrazenia slnečných bárok (Paulík 1999; 2000) potvrdzujú rozšírenie tejto mytológie v Karpatskej kotline doby bronzovej.

Pre slnečné božstvá neskorého európskeho praveku sa často predpokladá mýtus o zostupe do podzemného podsvetia (Green 1991, 122) na spôsob egyptského boha slnka Re a blízkovýchodných slnečných božstiev ako Šapšu alebo Šamaš (Taracha 2009, 109; West 1997, 470, 542). Za vhodnejšiu aproximáciu situácie v strednej Európe považujeme PIE božstvo slnka, ktoré nezostupovalo do sveta mŕtvych situovaného v podzemí. Hélios v noci putoval „nad vodami“ (Massetti, v príprave), pričom vo védskej tradícii slnko nielen že neschádza do

\footnotetext{
1 Autorka identifikovala konkrétne postavy/božstvá a upozorňuje, že zlatému poháru Hélia sa pôvodne prisudzovali epitetá typicky používané v súvislosti s lod’ami a poukazuje, že vo védskej tradícii motív nočnej plavby lodou „zdedili“ božskí bliženci (Nasátjovia), ktorí, presne ako Hélios, v noci putujú (okrídlenou) lod’ou vedení vtákmi.
} 


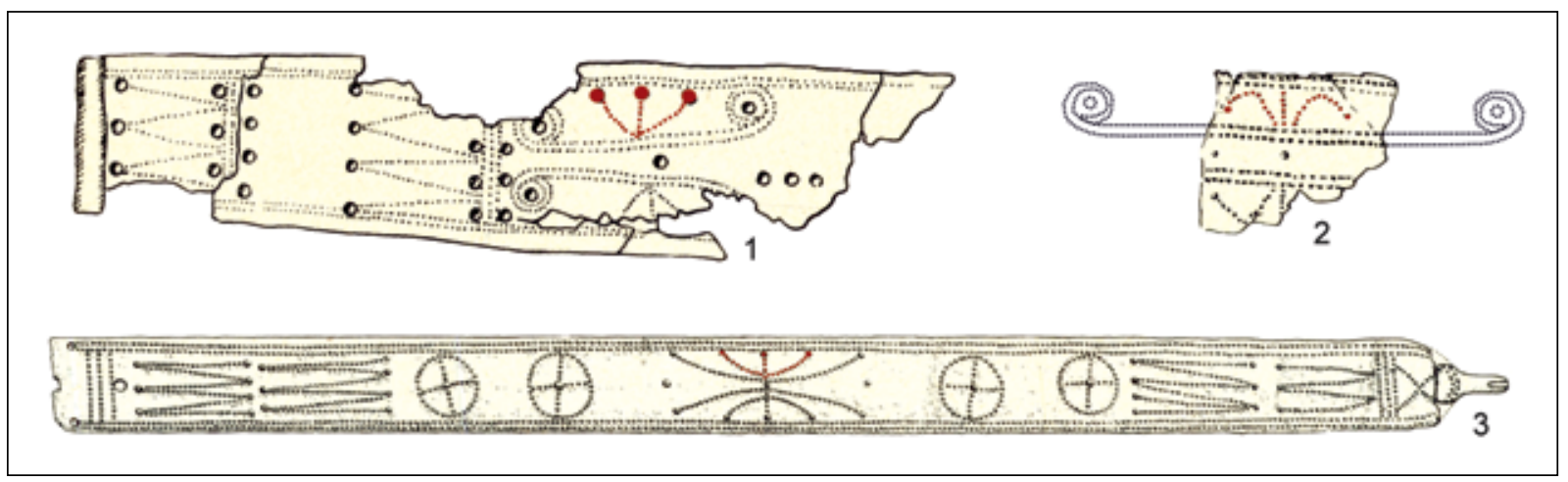

Obr. 3. Diadémy z Wojdalu (1), Łazarowíc (2) a opasok z Rościęcinu (3) so zrkadlovým obrazom bárok s ludskými postavami (podl'a Gedl 1975, tab. III: 5, 11; Kersten 1958, tab. 89: b).

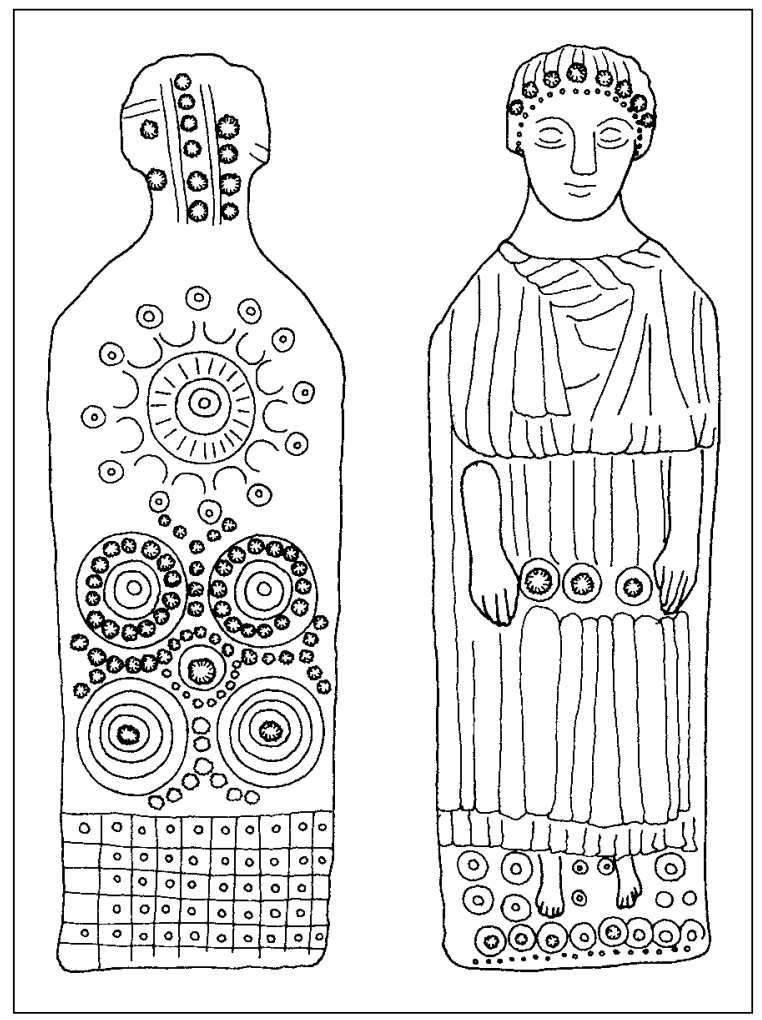

Obr. 4. Soška keltskej „Venuše“ (podla Green, 1991, 129, obr. 94).

podzemia, ale nikdy skutočne nezapadá: po dosiahnutí západného horizontu odvráti svoju jasnú stranu a nebadane sa vráti naprieč oblohou spät na východ - motív reprezentuje aj dánsky trundholmský slnečný disk, ktorý mal pozlátenú len jednu stranu (West 2007, 209, 210).

Niektorí autori, čerpajúci inšpiráciu z egyptských náboženských predstáv, interpretujú archeologicky doloženú asociáciu slnka so smrłou (napr. orientácia hrobov, solárne symboly náhrobných kameňov/stél a hrobovej keramiky) existenciou viery v znovuzrodenie na spôsob každodenného znovuzrodenia slnka (Panchenko 2012, 13; Wirth 2010, 8). Komparatívna indoeurópska mytológia vedie k odlišnej interpretácii: slnečné symboly znázorňovali vytúžený ciel' pomyselnej posmrtnej cesty duší.

Filologická analýza védskych textov a ich špecifických výrazov naznačuje, že duše „blažených“ v PIE kozmológii „,ǐsli k slnku“, aby prebývali na konci trasy slnka. Reflexy týchto predstáv zachytáva védska, grécka a zrejme aj avestská tradícia (Janda 2006, 23, 24). Poznáme množstvo komplementárnych reliktov tejto predstavy. Starogrécky autor Pindaros píše, že tam, kde po smrti prebývajú požehnaní, svieti slnko, ked' vo svete živých prebieha noc (Pindaros fr. 129.1). Podla Odysey (Homér 24.12) sa brána do sveta mŕtvych volá „Héliova brána“ (prekladá sa aj ako „slnečná brána“) a je to Kirké, dcéra Hélia, kto tam Odysea usmerní (10.561). V západných vetvách indoeurópskej tradície (keltskej, germánskej, baltskej) slnko po celodennej púti spočíva aj s božskými blížencami na ostrove v západnom mori, často identifikovaným ako ostrov blažených (Mallory/Adams 1997, 165).

\section{DISKUSIA}

Komplementárna výpoved' komparatívnej mytológie a archeológie indikuje výrazné vzájomné podobnosti a široké rozšírenie indoeurópskych tradícií asociovaných so slnečným božstvom. To znamená, že nepotrebujeme predpokladat šírenie slnečného kultu z vyspelejších civilizačných oblastí východného Stredomoria a Blízkeho východu do strednej Európy (Švecová 2004, 388), od ktorých sa indoeurópske tradície napriek niektorým vágnym podobnostiam líšia. 
Kriticky sa staviame aj k anachronickým tendenciám uvažovat' o slnečnom božstve doby bronzovej ako o božstve "apolónskeho typu“ (napr. Bouzek 1977; Švecová 2004). Apolón prebral slnečné atribúty až v 6. stor. p. n. 1. (Bilić 2016, 447; West 2007, 148; kontra Bouzek 1977, 197) a spájal viacero d’alších funkcií, netypických pre slnečné božstvá. Definovat’ solárne božstvá ako bohov „,apolónskeho typu“ preto považujeme za zavádzajúce a príliš ovplyvnené „antickým pohladom“ (Jelínek/Valent 2019, 63).

Na základe analýzy hmotnej kultúry považujeme za pravdepodobné, že v Karpatskej kotline doby bronzovej vystupovalo božstvo slnka v ženskej podobe. Ak táto koncepcia nadobudla širšie rozšírenie (čo môže byt predmetom dalšieho výskumu), je možné, že predstavovalo prototyp pre baltskú Saule, fragmentárne doložené germánske bohyne slnka Sunna a Sól, či niektoré slovanské folklórne tradície slnka v ženskej podobe (von Schroeder 1914-1916, ii. 40) a možné „relikty“ u Keltov: bohyňu termálneho prameňa $\mathrm{v}$ meste Bath nesúcu slnečné meno Sulis $^{2}$ (Birkhan 1997, 579, 580; Hoffender 2010, 97-100) a keltskú „Venušu“, ktorej hlinené sošky, masovo produkované v Galii a Porýní, niesli mimoriadne intenzívnu solárnu výzdobu evokujúcu slnečnú symboliku doby bronzovej (Green 1991, 127-130, s d’alšou literatúrou; obr. 4). Sošky podla všetkého znázorňujú bohyňu domáceho kultu chudobnejších vrstiev spoločnosti.
Širšie rozšírenie kultu indoeurópskej bohyne slnka môžu naznačovat slnečné symboly nesúce sošky na vozíkoch z Dupljaje (obr. 2), potenciálne znázorňujúce slnečné božstvo. Soška s dochovaným vtáčím záprahom sa obvykle interpretuje ako mužská (Bilić 2016, s literatúrou), niekedy ako ženská (Brandenstein 1956, 419; Kristiansen/ Larsson 2005, 150, 307) alebo queer (Matić 2010). Nesie ženský odev (Bouzek 1977, 197) a ženské ornamenty. Chýba plasticky znázornené poprsie, čo je u ženských sošiek kultúry Cirna Žuto-Brdo bežné (Chicideanu-Sandor/Chicideanu 1990, obr. 3-8). Na mieste pŕs nachádzame solárne symboly evokujúce prsia, podobne ako u záveskov typu Kisterenye (obr. 2). Umiestnenie týchto symbolov na prsiach (a bruchu) tiež pripomína sošky keltskej „Venuše“ (Green 1991, 129). Tvrdenie, že neurčitý „hrudkovitý “ útvar na spodnej-vnútornej strane sošky znázorňuje penis (Podborský 2006, 232, tab. 56: 4a) nemôžu dostupné vyobrazenia jednoznačne potvrdit: môže íst̉ o artefakt neuhladeného materiálu (Holenweger 2011, 134, poznámka na str. 446).

\section{Podakovanie}

Za cenné pripomienky autori d’akujú Barbore Machajdíkovej, PhD. Táto práca bola podporovaná Agentúrou na podporu výskumu a vývoja na základe Zmluvy č. APVV-15-0491.

\section{LITERATÚRA}

Anthony 2017 - D. Anthony: Archaeology and Language: Why Archaeologists Care About the Indo-European Problem. In: P.J. Crabtree/P. Bogucki (eds.): European Archaeology as Anthropology: Essays in Memory of Bernard Wailes. Philadelphia 2017, 9-39.

Bilić 2016 - T. Bilić: The swan chariot of a solar deity: Greek narratives and prehistoric iconography. Documenta Praehistorica 43, 2016, 445-466.

Birkhan 1997 - H. Birkhan: Kelten. Versuch einer Gesamtdarstellung ihrer Kultur. Wien 1997.

Blajer 1990 - W. Blajer: Skarby z wczesnej epoki brazu na ziemiach polskich. Wrocław - Warszawa - Kraków Gdańsk - Łódź 1990.

Bóna 1992 - I. Bóna: Bronzeguss und Metallbearbeitung bis zum ende der mittleren Bronzezeit. In: W. Meier-Arendt (Hrsg.): Bronzezeit in Ungarn: Forschungen in Tell-Siedlungen an Donau und Theiss. Frankfurt am Main 1992, 48-65.

Bouzek 1977 - J. Bouzek: Sonnenwagen und Kesselwagen. Archeologické rozhledy 29, 1997, 192-202.

Brandenstein 1956 - W. Brandenstein: Die Göttin von Dupljaja. Carinthia I, 146, 1956, 419-424.
Buchvaldek a i. 1997 - M. Buchvaldek/V. Moucha/M. Popelka/I. Vojtěchovská: Katalog šňůrové keramiky v Čechách XI - XIV. Kladensko, Slánsko, Kralupsko a Praha-západ. Praehistorica 22. Varia archeologica 7, 1997, 113-253.

Gedl 1975 - M. Gedl: Kultura przedtużicka. Wrocław - Warszawa - Kraków - Gdańsk 1975.

Gimbutas 1963 - M. Gimbutas: The Balts. London 1963.

Green 1991 - M. Green: The Sun-Gods of Ancient Europe. London 1991.

Haas 1994 - V. Haas: Geschichte der Hethitischen Religion. Leiden 1994.

Hänsel 2012 - B. Hänsel: Zum Aufkommen des Vogelsonnenbarkem-Symbols vor der Urnenfelderzeit. In: R. Kujovský/V. Mitáš (ed.): Václav Furmánek a doba bronzová. Nitra 2012, 109-117.

Hoffender 2010 - A. Hoffender: Vestiges of sun worship among the Celts. In: A. Gail (ed.): Sun Worship in the Civilisations of the World. Pandanus 10'. Nature in Literature, Art, Myth and Ritual 4/2. Praha 2010, 85-107.

Holenweger 2011 - E. Holenweger: Die anthropomorphe Tonplastik der Mittel und Spätbronzezeit im mittel-bis

\footnotetext{
2 Prinajmenšom pôvodne išlo o bohyňu slnka. Slnečné božstvá sa u Keltov asociujú s horúcimi prameňmi, okrem keltskej „Venuše“ napr. aj keltský „Apolón“ (Green 1991, 110, 118).
} 
unterdanubischen Gebiet. Dizertačná práca. Filozofická fakulta, Universität des Saarlandes. Saarbrücken 2011. Nepublikované.

Chicideanu-Sandor/Chicideanu 1990 - M. Chicideanu-Sandor/I. Chicideanu: Contributions to the study of the Girla Mare anthropomorphic statuettes. Dacia NS 34, 1990, 53-75.

Janda 2006 - M. Janda: The Religion of the Indo-Europeans. In: K. Jones-Bley (ed.): Proceedings of the Seventeenth Annual UCLA Indo-European Conference. Washington D.C. $2006,1-30$.

Jankovits 2017 - K. Jankovits: Die bronzezeitlichen Anhänger in Ungarn. Budapest 2017.

Jelínek/Valent 2019 - P. Jelínek/D. Valent: Náboženské ikonografie v staršej dobe bronzovej. Zborník SNM 113. Archeológia 29, 2019, 47-76.

Kaliff 2007 - A. Kaliff: Fire, water, heaven and earth: ritual practice and cosmology in ancient Scandinavia: an IndoEuropean perspective. Stockholm 2007.

Kaul 1998 - F. Kaul: Ships on Bronzes. A Study in Bronze Age Religion and Iconography. Copenhagen 1998.

Kaul 2008 - F. Kaul: Sotetorp - endnu engang. Adoranten 2007, 2008, 51-75.

Kaul 2018 - F. Kaul: The Shape of the Divine Powers in Nordic Bronze Age Mythology. In: B. L. Christensen/ J. T. Jensen (eds.): Religion and material culture. Turnhout 2018, 199-225.

Keith 1925 - A. B. Keith: The Religion and Philosophy of the Veda and Upanishads. Cambridge (Massachusetts) 1925.

Kersten 1958 - K. Kersten: Die Funde der Älteren Bronzezeit in Pommern. Hamburg 1958.

Kiss 2012 - V. Kiss: Middle Bronze Age Encrusted Pottery in Western Hungary. Budapest 2012.

Kossack 1954 - G. Kossack: Studien zum Symbolgut der Urnenfelder- und Hallstattzeit Mitteleuropas. Berlin 1954.

Kristiansen/Larsson 2005 - K. Kristiansen/T. B. Larsson: The Rise of Bronze Age Society. Cambridge 2005.

Kristiansen 2013 - K. Kristiansen: The Nebra find and early Indo European religion. In: H. Meller/F. Bertemes (Hrsg.): Der Griff nach den Sternen. Wie Europas Eliten zu Macht und Reichtum kamen. Halle 2013, 431-437.

Machnik a i. 1978 - J. Machnik/B. Gediga/J. Miśkiewicz/ W. Hensel: Prahistoria ziem polskich. Tom III. Wczesna epoka brazu. Wrocław - Warszawa-Kraków -Gdańsk 1978.

Mallory/Adams 1997 - J. P. Mallory/D. Q. Adams: Encyclopedia of Indo-European Culture. London 1997.

Mandausová 2012 - A. Mandausová: „Sluneční“ symboly v hrobech kultury se šňůrovou keramikou. Bakalárska práca. Katedra archeológie Filozofickej fakulty Západočeskej univerzity v Plzni. Plzeň 2012. Nepublikované.

Massetti 2019 - L. Massetti: Antimachus' enigma. On Erytheia, the Latvian Sun-goddess and a red fish. The Journal of Indo-European Studies 47, 2019, 223-240.
Massetti, v príprave - L. Massetti: The chariot, the horse, the winged depas. Once again on the journey of the Sun-god. V príprave.

Matić 2010 - U. Matić: Dupljajska kolica i tela koja nešto znače. Genero 14, 2010, 129-159.

Panchenko 2012 - D. Panchenko: Scandinavian background of Greek Mythic Cosmography: The Sun's water transport. Hyperboreus 18, 2012, 5-20.

Paulík1999-J.Paulík: Nálezhlinenejvtáčejlod'ky v Dvorníkoch-Posádke I. Zborník SNM 43. Archeológia 9, 1999, 29-54.

Paulik2000-J.Paulík: Nálezhlinenejvtáčejlod'ky v Dvorníkoch-Posádke II. Zborník SNM 44. Archeológia 10, 2000, 30-60.

Pinault 2017 - G.-J. Pinault: The ultimate origin of ProtoIndo-European 'sun'. In: J. A. Álvarez-Pedrosa/ A. Bernabé/E. Luján/F. Presa (eds.): Ratna. Homenaje a la profesora Julia Mendoza. Madrid 2017, 137-162.

Podborský 2006 - V. Podborský: Náboženství pravěkých Evropanu. Brno 2006.

Reiter 2014 - V. Reiter: Das Grab mit dem Anhänger Typ Včelince aus Neumarkt an der Ybbs (Bez. Melk). Archäologisches Korrespondenzblatt 44, 2014, 369-376.

von Schroeder 1914-1916 - L. von Schroeder: Arische Religion (2 zväzky). Leipzig 1914-1916.

Slaná 2019 - A. Slaná: Bronzové súčasti slávnostného kroja žien stredodunajskej mohylovej kultúry. In: L. Benediková/G. Březinová/E. Horváthová/S. Stegmann-Rajtár (ed.): Fragmenty času. Venované Elene Miroššayovej k 70. narodeninám. Študijné zvesti AÚ SAV. Supplementum 1. Nitra 2019, 431- 449.

Švecová 2004 - R. Švecová: Slnečná symbolika v náboženskom kontexte doby bronzovej. In: E. Kazdová/ Z. Měřínský/K. Šabatová (ed.): K poctě Vladimíru Podborskému. Brno 2004, 385-393.

Taracha 2009 - P. Taracha: Religions of Second Millennium Anatolia. Dresdner Beiträge zur Hethitologie 27. Wiesbaden 2009.

West 1997 - M. L. West: The East Face of Helicon: West Asiatic Elements in Greek Poetry and Myth. Oxford 1997.

West 2007 - M. L. West: Indo-European Poetry and Myth. Oxford 2007.

Wirth 2010 - S. Wirth: Sonnenbarke und zyklisches Weltbild. In: H. Meller/F. Bertemes (Hrsg.): Der Griff nach den Sternen. Wie Europas Eliten zu Macht und Reichtum kamen. Halle 2010, 501-515.

Wodtko/Irslinger/Schneider 2008 - D. Wodtko/B. Irslinger/ C. Schneider: Nomina im Indogermanischen Lexikon. Heidelberg 2008.

\section{PRAMENE}

Homér: Odysseia. Preložil Rudolf Mertlík. Praha 1984.

Pindaros: The Odes of Pindar including the Principal Fragments. Preložil John Sandys. London 1915.

Mgr. Dušan Valent dus.valent@gmail.com

Mgr. Pavol Jelínek, PhD.

Slovenské národné múzeum-Archeologické múzeum

Žižkova 12, P.O.BOX 13

SK - 81006 Bratislava

pavol.jelinek@gmail.com 


\title{
Séhul and Her Representations in the Material Culture of the Bronze Age
}

\author{
Dušan Valent - Pavol Jelínek
}

SUMMARY

In the Bronze Age material culture of the Carpathian Basin, we find evidence of a possible sun goddess in the form of anthropomorphic moon-shaped and gynecomastomorphic pendants representing a figure or a female torso decorated with four-spoked wheels and other solar symbols. We find parallels to these pendants on pottery and the Dupljaja figurines (Fig. 2). Additional anthropomorphic portrayals that can be associated with a solar deity can be found in the form of figures carried by barges (Fig. 3). They are associated with Nordic circle and in Central Europe they are known from Polish bronze diadems with stylized, mirroring barges carrying a triad of figures. Similar portrayal can be found on a belt found in Rościęcin featuring solar symbols, possibly indicating the function of these figures. Triadic compositions on ships seem to constitute an iconographic group with internal meaning. These mirroring images of ships appear in the Carpathian Basin during the Middle Bronze Age.

Since Central Europe was most likely Indo-Europeanized during the $3^{\text {rd }}$ millennium BC, Indo-European comparative mythology may be an important tool to bet-

Fig. 1. Bronze age solar symbols (after Kossack 1954, pl. 8: 15-17; 9: 4, 5) and their natural inspiration (photo by F. Tóth).

Fig. 2. Anthropomorphic pendants with solar symbolism, figurines and chariots from Dupljaja (after Jankovits 2017, pl. 30: 988, 990, 991, 994-996, 1002, 1003; 43: 1290, 1294; Podborský 2006, pl. 56: 4). ter understand the Bronze Age religion of the Carpathian Basin and a reconstructed Proto-Indo-European (PIE) sun deity can be considered a close approximation of the Carpathian Bronze Age sun goddess. Based on archeology and Indo-European comparative mythology, a case can be made for the existence of widely spread and complex mythology associated with early Indo-European (Bronze Age) solar deities, that is probably PIE in origin and despite superficial similarities distinct from Near-Eastern or Egyptian solar mythologies. Evidence of it can be found also in the Carpathian Basin. In contrast to Near-Eastern and Egyptian solar deities, PIE solar deity did not enter a subterranean underworld and was not associated with rebirth, but most likely with the desired destination in the afterlife. This may lead to different interpretations of some cult- and grave related archeological finds featuring solar symbolism. If more widespread, the proposed Bronze Age sun-goddess may be represented by the Dupljaja figurines and ancestral to later sun goddesses Saule (Baltic), Sól and Sunna (Germanic), and Sulis (Celtic), as well as the solar deity represented by figurines of Celtic 'Venus' (Fig. 4).

Fig. 3. Diadems from z Wojdal (1), Łazarowice (2) and a belt from Rościęcin (3) with a mirror image of barges carrying human figures (after Gedl 1975, pl. III: 5, 11; Kersten 1958, pl. 89: b).

Fig. 4. Figurine of Celtic „Venus“ (after Green 1991, 129, fig. 94). 